\title{
EGFR NM_005228.3:c.2235_2252del18
}

National Cancer Institute

\section{Source}

National Cancer Institute. EGFR NM 005228.3:C.2235 2252del18. NCI Thesaurus. Code C98549.

A deletion of 18 nucleotides from the coding sequence of the EGFR gene from position 2235 through 2252. 